\title{
NCATE and Collegiate Libraries
}

\author{
By DONALD S. MAC VEAN
}

The National Council for Accreditation of Teacher Education, commonly referred to as NCATE, is evaluating the teacher education programs in the nation's colleges and universities. In these evaluations some attention is given to the library and therefore NCATE and its standards and procedures should be of concern to academic librarians.

Before describing NCATE practices as they relate to libraries, perhaps some background information about the council itself and accreditation of teacher education programs will be useful. Prior to 1952 the American Association of Colleges for Teacher Education was the only national agency which accredited teacher education programs, but it was refused recognition by the National Commission on Accrediting because of the restricted and nonrepresentative character of its membership. ${ }^{1}$ As a result of this action, NCATE was organized in 1952 by the representatives of a number of educational associations interested in teacher education, and in 1956 it was recognized by the national commission as the sole national agency responsible for accreditation of teacher education.

There have been changes in the membership of the council since 1952 , but at present the organizations interested in teacher education and the number of representatives appointed by them to the council are as follows: American Association of Colleges of Teacher Education, 7; Council of Chief State School Officers, 1; National Association of State Directors of Teacher Education and Certification, 1; National Education Association on the

${ }^{1}$ William K. Selden. "Why Accredit Teacher Education ?"' The Journal of Teacher Education, XI (June $1960), 189$.
Dr. Mac Vean is Assistant Librarian in Charge of Reader Services, Ball State Teachers College, Muncie, Indiana.

recommendation of the National Commission on Teacher Education and Professional Standards, 6; National School Boards Association, 1; and an ad hoc committee appointed by the National Commission on Accrediting, 3. ${ }^{2}$ The last mentioned group of representatives on the council is selected from institutions which train teachers but which are not members of the American Association of Colleges for Teacher Education, the purpose being to broaden representation. ${ }^{3}$

The purposes of NCATE are, briefly, to formulate "policies, standards, and procedures" for the accreditation of teacher education programs and to inspect and accredit or refuse to accredit such programs. ${ }^{4}$ As a result of such activities, it hopes both to stimulate institutional self-evaluation and to insure high quality instructional programs for teachers in all regionally accredited institutions.

Any institution which offers a fouryear teacher training program and which is already accredited by its state department of education and one of the regional associations may apply to NCATE for evaluation and accreditation. Such application for accreditation is voluntary, however, and only those institutions which believe they have reasonable expectation of being accredited are encouraged to apply. Along with the application a great deal of statistical and other data prepared

\footnotetext{
${ }^{2}$ The National Council for Accreditation of Teacher Education, A Statement of Purposes, Policies, and Procedures (Washington: The Council, 1960), p.[i]. ${ }^{3}$ Ibid.

Ibid., p.2.
} 
in accord with the official guide must be sent to NCATE headquarters. Then a visitation date is set and a team of evaluators selected. In selecting the evaluators NCATE uses the list of persons nominated by the member associations. A shorter list is submitted to the institution scheduled for evaluation, and it may strike the names of persons who would be objectionable. From the remaining names the NCATE staff selects the team of evaluators which will actually visit the institution. ${ }^{5}$

Once the evaluative visit has been completed, a report is prepared by the team, and it is sent to the council. After consideration, the council may do one of three things: it may grant full accreditation, grant provisional accreditation, or deny accreditation of any kind.

At the close of 1962392 colleges were accreditated by NCATE. Of this number, 284 had been accredited by AACTE prior to 1954 and were transferred to the accredited list of NCATE without further inspection or evaluation. ${ }^{6}$ Since then, 141 institutions have been evaluated; 108 have been accredited and thirty-three have been denied accreditation. ${ }^{7}$

NCATE has not revealed the specific reasons for failure to accredit the thirtythree institutions referred to above. Such information is not made public but is, of course, given in detail to the institutions affected. In answer to an inquiry sent to NCATE, Robert S. Thurman, assistant director, replied that no institution has been denied accreditation solely because of inadequate library facilities but that certain institutions had been given only provisional accreditation partly for this reason. ${ }^{8}$

\footnotetext{
5 The American Association of Colleges for Teacher Education, Source Book on Accreditation of Teacher Education (Washington: The Association, 1962), pp. 9-10.

- Letter from Robert S. Thurman, Assistant Director of NCATE, December 17, 1962.

${ }^{7}$ Ibid.

8 Ibid.
}

What happens when an institution is denied accreditation by NCATE? Does it mean that it may no longer train teachers? Actually, it may have little or no effect at all for the time being. The institution may continue to train teachers and, if they are granted certificates or licenses by a particular state, they may teach in the schools of that state. NCATE does not issue teachers' certificates to individuals but only accredits teacher education programs in colleges and universities. There are, however, some positive values for an institution to be accredited by NCATE. First of all, as mentioned earlier, it is the only national agency authorized by the National Commission on Accrediting to accredit teacher education curricula. Thus, it lends prestige to an institution to have the council's stamp of approval on an important part of its program. Second, at the present time, twenty-nine states grant reciprocity in matters of certification to out-of-state graduates if they are products of NCATE-approved institutions. ${ }^{9}$ Such reciprocal arrangements probably will be extended in the future. If, as has been recommended, ${ }^{10}$ all states should stipulate that only graduates of NCATE-approved institutions will be certified or licensed, NCATE will have a powerful weapon at hand, and concern over its standards and procedures, which are now being questioned in various quarters, will be greatly intensified.

There have been numerous objections to NCATE, the following having been reported most often: (1) that the members of the council represent educational associations (too often the National Education Association or its subsidiary units) and state departments of education, and not colleges and universities which actual-

\footnotetext{
9 "Will Wisconsin Accredit NCATE?" Phi Delta Kappan, XLIV (January 1963), 156.

10 National Education Association of the United States. National Commission on Teacher Education and Professional Standards, New Horizons for the Teaching Profession; a Report of the Task Force on New Horizons in Teaching Education and Professional Standards (Washington: The Association,
} $1961)$, p.115. 
ly educate teachers; ${ }^{11}$ (2) that NCATE is too dependent on the same associations for its financial support, thus compromising its independence and objectivity; ${ }^{12}$ (3) that there is no need for separate and special accrediting of teacher education, and that accreditation by regional associations is sufficient. ${ }^{13}$ In regard to the last mentioned point, it should be stated that the primary concern of the regional associations in evaluating colleges and universities is with the quality of the liberal arts or general education program of the school and only secondarily with the professional curricula. Thus, those persons primarily interested in teacher education are not satisfied that such accreditation is sufficient. Just as there is separate and special accreditation for engineering and law, they believe the same is pertinent to and necessary for teacher training. This last point illustrates another basic difference between educationists and devotees of the liberal arts. The former believe that in addition to a general education there is an identifiable sequence of professional courses and experiences which the prospective teacher should take; many of the latter group, however, believe that, if students know their subject matter well, they can teach it satisfactorily in the elementary and secondary schools, and that little or no professional training is necessary. It is probably safe to add that in the minds of such people, teaching is not a profession at all, and thus no special accreditation of teacher education curricula is necessary. ${ }^{14}$

\section{NCATE STANDARDS}

The current statement of NCATE

\footnotetext{
11 Resolution proposed by the Commission on Teacher Education at the 1963 annual meeting of the Association of American Colleges, Liberal Education, XLIX (March 1963), 110.

12 "Controversy in Accreditation," Council for Basic Education Bulletin, VII (March 1963), 1.

${ }^{13}$ William K. Seldon. "Basic Issues in Accreditation of Teacher Education," Liberal Education, XLVII (December 1961), 583.

14 For a summary of additional eriticisms of NCATE see "Will Wisconsin Accredit NCATE?" Op. cit., pp.155-56.
}

standards appears in a twenty-four page document issued by the council in $1960 . .^{15}$ It is divided into seven sections or standards, and only the seventh, entitled "Facilities and Instructional Materials for Teacher Education," makes any reference to what may be termed library materials. It states that "a materials laboratory or center should be maintained either as a part of the library or as a separate unit, ${ }^{16}$ that it should contain school textbooks, courses of study, standardized tests, and audio-visual aids, and that it should be directed by a qualified faculty member. ${ }^{17}$ It also states that the basic books and periodicals should be available in the library but that the number of titles and the number of copies of each should be determined by the scope of the program and the number of students respectively. In the guide accompanying this standard a report is requested on housing of the professional education library, the amount spent during the previous year on library books and periodicals, the orders placed during the same period for professional books, and procedures employed for keeping the collection upto-date. ${ }^{18}$

With these few brief statements the library and library materials are dispensed with. It may seem that the NCATE standards are only remotely concerned with the library. Essentially only three types of materials are mentioned-professional education literature, curriculum materials, and audio-visual aids-and some may argue that only provision of the first category is a legitimate library function. It is true that the NCATE standards do not insist that such materials be housed and serviced in the library, but it is common knowledge that in many collegiate institutions, especially those which educate large numbers of teachers, they are

\footnotetext{
15 National Council for Acereditation of Teacher Education. Standards and Guide to Accreditation of Teacher Education (Washington: The Council, 1960). 16 Ibid., p.22.

${ }^{17}$ Ibid.

15 Ibid., p.23.
} 
found there, and apparently there is a definite trend to put them there.

\section{IMPLICATIONS FOR LIBRARIANS}

If, in its evaluative and accrediting activities, NCATE is to concern itself with the college or university library, even if only a small part of it, it would seem that librarians should be concerned in several respects: (1) some professional library association such as ACRL should have at least one representative on NCATE; (2) a college or university librarian should be a member of each visiting team for the purpose of evaluating library holdings and services related to teacher education; ${ }^{19}$ and (3) perhaps most basic of all, librarians should insist that the standards relating to library materials be revised in such a way that they are more explicit and meaningful. Webster defines a standard as "a definite level or degree of quality that is proper and adequate for a specific purpose," or as "something that is set up and established by authority as a rule for the measure of quantity, weight extent, value, or quality." If such a definition of standards is to be accepted in this instance, it seems obvious that the present NCATE standards are inadequate. This would be true

\footnotetext{
19 At present a specialist in library education (who may or may not be a college or university librarian) nominated by the American Library Association or some institution is a member of the NCATE teams visiting those institutions which offer an extensive undergraduate program in school librarianship. This person is not, however, concerned with library holdings and services.
}

even if all were in agreement with the present practice of ACRL and the various regional accrediting associations of expressing their library standards in qualitative terms. There is still a need for the standards to be expressed in precise and explicit enough terms so that a reasonably uniform and objective application of standards may be made. As the standards are written, two libraries which are quite similar in terms of holding, facilities, budget, and staff could be evaluated by different teams with completely different results. One could be highly praised and the other severely criticized. There is great latitude within which the subjective judgment of the evaluators can range.

This article is not being written for the purpose of joining the chorus of protest which is being heard about NCATE and its policies. Actually, there is great need for such an agency. In 1962-63, of the 1,447 accredited institutions in the United States offering the bachelor's or higher degree 999 were training teachers; ${ }^{20}$ it seems obvious that some national agency must have the authority and the responsibility both to prepare and to enforce acceptable standards for such programs. It is apparent also, however, that the standards themselves should be defensible and that the persons assigned to evaluate each institution should be qualified in all respects.

${ }^{20}$ U. S. Office of Education. Education Directory, 1962-63, Part 3, Higher Education (Washington: Government Printing Office, 1963), p.10.

\section{Library History Roundtable}

The American Library History Roundtable will hold its annual program meeting in connection with the ALA conference in St. Louis on Monday, June 29, at 4:30 P.M.

Two papers of distinction and excitement will be presented: (1) "The Harvard Law Library and Its Librarians," by Earl Borgeson, librarian of the Harvard law library, and (2) "Two New York Societies of Librarians," by Wayne Shirley, librarian of Wentworth Institute.

The two New York societies of librarians are the Archons Colophon, a group of men who meet four times a year at Columbia University for dinner and a program, and the Melvil Dui Chowder and Marching Association which includes men librarians who meet informally four times a year for dinner and discussion. 